\title{
Comparative Studies of Steel, Bamboo and Rattan as Reinforcing Bars in Concrete: Tensile and Flexural Characteristics
}

\author{
Adekunle P. Adewuyi ${ }^{*}$, Adegboyega A. Otukoya ${ }^{1}$, Oluwole A. Olaniyi², \\ Oladipupo S. Olafusi1 \\ ${ }^{1}$ Department of Civil Engineering, Federal University of Agriculture, Abeokuta, Nigeria \\ ${ }^{2}$ Department of Civil Engineering, Ladoke Akintola University of Technology, Ogbomoso, Nigeria \\ Email: adewuyiap@funaab.edu.ng, apadewuyi@yahoo.co.uk, azeezotus@yahoo.com, \\ wole.olaniyi@yahoo.com, olafusidipo@yahoo.com
}

Received 12 May 2015; accepted 13 June 2015; published 18 June 2015

Copyright (C) 2015 by authors and Scientific Research Publishing Inc.

This work is licensed under the Creative Commons Attribution International License (CC BY). http://creativecommons.org/licenses/by/4.0/

(c) (i) Open Access

\section{Abstract}

This study comparatively evaluated the flexural performance and deformation characteristics of concrete elements reinforced with bamboo (Bambusa vulgaris), rattan (Calamuc deerratus) and the twisted steel rebars. The yield strength (YS), ultimate tensile strength (UTS) and the elongation of 50 specimens of the three materials were determined using a universal testing machine. Three beams of concrete strength $20 \mathrm{~N} / \mathrm{mm}^{2}$ at age 28 days were separately reinforced with bamboo, rattan and steel bars of same percentage, while the stirrups were essentially mild steel bars. The beams were subjected to centre-point flexural loading according to BS 1881 to evaluate the flexural behaviour. The YS of bamboo and rattan bars were $13 \%$ and $45 \%$ of that of steel respectively, while their UTS were $16 \%$ and $62 \%$ of that of steel in the same order. The elongation of bamboo, rattan and steel were $7.42 \%, 10 \%$ and $14.7 \%$ respectively. The natural rebars were less than the $12 \%$ minimum requirement of BS 4449 . The load-deflection plots of bamboo and steel RC beams were quadratic, while rattan RC beams had curvilinear trend. The stiffness of bamboo RC beams (BB) and rattan RC beams (RB) were $32 \%$ and $13.5 \%$ of the stiffness of steel RC beams (SB). The post-first crack residual flexural strength was $41 \%$ for BB and SB, while RB was $25 \%$. Moreover, the moment capacities of $B B$ and $R B$ corresponded to $51 \%$ and $21 \%$ respectively of the capacity of steel RC beams. The remarkable gap between the flexural capacities of the natural rebars and that of steel can be traced not only to the tensile strength but also the weak bonding at the bar-concrete interface. It can be concluded that the bamboo bars are suitable rebars for non-load bearing and lightweight RC flexural structures, while more pre-strengthening treatment is required more importantly for rattan for improved interfacial bonding and load-carrying capacity.

"Corresponding author.

How to cite this paper: Adewuyi, A.P., Otukoya, A.A., Olaniyi, O.A. and Olafusi, O.S. (2015) Comparative Studies of Steel, Bamboo and Rattan as Reinforcing Bars in Concrete: Tensile and Flexural Characteristics. Open Journal of Civil Engineering, 5, 228-238. http://dx.doi.org/10.4236/ojce.2015.52023 


\section{Keywords}

\section{Reinforcing Bars, Bamboo, Rattan, Tensile Characteristics, Flexural Strength, Concrete, Load-Carrying Capacity}

\section{Introduction}

The overall sustainable economic growth, productivity, and the well-being of a nation depend heavily on the functionality, reliability, and durability of its constructed facilities. However, aside the environmental and operational condition, the constituent materials accounting for the increasing cases of structural deficiency and functional obsolescence are recorded in the built environment (Adewuyi et al. [1] [2], Adewuyi and Wu [3]).

Ascendancy of concrete over other construction materials is not unconnected to its flexibility of shape, strength, durability and response to its environment and economy. Its tensile strength is about $10 \%$ of its compressive strength (Neville [4], Kosmatka et al. [5], Mehta and Monteiro [6], Mosley et al. [7]). Applicability of natural or waste materials in partial replacement of cement and aggregate are subjects that have received attention in recent years. Previous studies had been carried out by Adewuyi and Ola [8] and Adewuyi and Adegoke [9]) on utilization of unwanted materials such as waterworks sludge ash and periwinkle shells as partial replacement for cement and coarse aggregated respectively.

Reinforced concrete (RC) structures account for majority of the constructed facilities globally and their performance is greatly influenced by the properties of the reinforcing bars. The transfer of stress from concrete to steel is made possible through effective bond between concrete and the reinforcement. Previous studies on the chemical, physical and strength characteristics of steel reinforcing materials revealed the dangers of maximizing profit at the expense of quality, a situation that pose a major challenge to the structural reliability and durability of buildings and civil infrastructure (Basu et al. [10], Olaniyi [11], Kolade [12]). Although extensive studies have been carried out on synthetic and natural non-ferrous reinforcing materials in the past decades, natural reinforcement still remains a dynamic field of further investigation.

The development of synthetic fibre reinforced polymers (FRPs) as an emerging technology for concrete structures has been tested and proved successful for vast applications. The pioneer studies on the evolution and behaviour of concrete structures reinforced with different kinds of inorganic and organic FRP bars such as glass, carbon, and aramid fibers were reported by Nawy et al. [13], Nawy and Neuwerth [14], Yamasaki et al. [15], Faza and GangaRao [16], and Bakis et al. [17]. However, the non-affordability of these materials is a major drawback to its global acceptance for buildings and public infrastructure.

Numerous studies have been carried out on natural reinforcing materials such as wood (Andonian et al. [18]), jute (Manzur and Aziz [19]), bamboo (Kankam et al. [20]), raffia palm (Kankam. [21]) and palm stalk (Kankam [22]). Attention is gradually been focused on the use of bamboo (Bambusa vulgaris), rattan (Calamus deerratus) and other natural fiber reinforcing materials as alternative reinforcements in concrete especially for low-cost housing for rural communities. In rural communities of Ghana, babadua is used in thatching and its stems are tied into framework of houses before daubing with mud (Schreckenbach and Abenkwa [23]).

Bamboo is a natural perennial grass-like composite and contains ligno-cellulosic-based natural fibers. It occurs in the natural vegetation of many parts of tropical, subtropical and mild temperature regions, with about 1250 species identified throughout the world (McClure [24], Austin and Ueda [25]). There are seven species of bamboo in Nigeria among which bambusa vulgaris constitutes 80\% (Falade and Akeju [26] [27]). Bamboo is an extremely strong fiber with twice the compressive strength of concrete and roughly the same strength-to-weight ratio of steel in tension. Many researchers have tried to use bamboo as substitute of steel in reinforced concrete. Chembi and Nimityongskul [28] and Winarto [29] have reported its use in construction of water tanks. Ghavami [30] reported its use as reinforcement for lightweight concrete beams. Venkateshwarlu and Raj [31] and Raj [32] developed bamboo-based ferrocement slab elements for roofing/flooring purpose in low cost housing. Kankam et al. [33] studied its applications in RC slabs. Falade and Akeju [26] [27], found the maximum tensile strength of $133.54 \mathrm{~N} / \mathrm{mm}^{2}$ for bamboo as opposed to $204-250 \mathrm{~N} / \mathrm{mm}^{2}$ obtained by Alade et al. [34]. Further investigation showed that bamboo RC beams had $134.65 \%$ of the load-carrying capacity of the unreinforced beams at 28day. The load capacity of mild steel RC beams was 1.5 times that of its equivalent bamboo RC beams (Akeju and Falade [35]). 
Rattan is comparatively cheaper than wood and bamboo; and has tremendous a growth potential in rural areas. Whereas the mechanical properties and behaviour of steel have been thoroughly studied and well documented. Mahzuz et al. [36] determined ultimate tensile strength, yield strength, Young's modulus and bond strength (when embedded in concrete) of rattan samples cut from three years and older trees. Baba [37], Ghavami [30] [38], and Mahzuz et al. [39] reported comprehensive studies on the behaviour of bamboo, but only very few comprehensive data are available on tensile and flexural properties of rattan (Chowdhury [40]. Mahzuz et al. [41] determined the yield strength, ultimate strength and modulus of elasticity of a rattan (Calamus guruba) through experimental investigation. The performance of rattan RC beams was evaluated in flexure and shear. The result showed that bond stress was $42 \%$ lower position than the corresponding experimental shear stress.

Lucas and Dahunsi [42] found that the interfacial bond strengths of rattan-concrete were in the range 0.082 $0.598 \mathrm{~N} / \mathrm{mm}^{2}$ depending on the species, concrete grade and other natural conditions. The experimental results of $0.34-0.38 \mathrm{~N} / \mathrm{mm}^{2}$ obtained by Cox and Gyemayer [43] fall within the range. Moreover, Youssef [44] gave 0.56 $0.68 \mathrm{~N} / \mathrm{mm}^{2}$ for some bamboo species bonded with concrete. All the findings fall between 3.94 and $28.86 \%$ of steel-concrete bond strength of $2.07 \mathrm{~N} / \mathrm{mm}^{2}$ of comparable concrete grade (Neville and Brook [45]). It was found that the moduli of elasticity for three species of Rattan were 3396, 516 and 11,106 N/mm ${ }^{2}$ for C. deerratus, E. macrocarpa and L. secundiflorum respectively (Lucas and Dahunsi [46]). The use of rattan reinforcement in lieu of conventional steel reinforcements requires better understanding under axial loading and performance conditions. Akinyele and Olutoge [47] investigated the flexural behavior of two-way slabs reinforced with rattan and conventional reinforcements under axial loading.

Although extensive literature abound on natural rebars in reinforced concrete structures, no clear comparative investigations had been done on steel, bamboo and rattan under similar geometric and loading conditions to determine the relative capacities and thereby establishing the limits to the applicability of the natural rebars. Hence, this paper presents the experimental study to comparatively evaluate the flexural behaviour of concrete beams reinforced with steel, bamboo and rattan. The physical and tensile strength properties of steel, bamboo and rattan were first determined and the flexural capacities of concrete beams reinforced with the individual materials bars were evaluated. The limits of usage of bamboo and rattan bars as reinforcement were established with respect to the steel RC beams.

\section{Experimental Investigations}

Structural behaviour of concrete beams reinforced with bamboo, rattan and steel was comparatively evaluated experimentally in two folds. First, the tensile parameters of the reinforcing materials were determined in the laboratory. Second, the load-carrying capacities of RC concrete beams wherein bamboo, rattan and steel were separately employed as the longitudinal bars were investigated. Detailed experimental plan is described as follows.

\subsection{Tensile Strength Properties of Steel, Bamboo and Rattan Bars}

The physical and tensile strength properties of steel, bamboo and rattan were determined experimentally using a 600 kN capacity Avery-Denison servo-hydraulic universal testing machine (UTM) shown in Figure 1. This was done in line with ASTM specifications and compared with the requirements of BS 4449 [48]. Twisted steel bars of sizes between 10 and $12 \mathrm{~mm}$ of the same brand were randomly sourced from major construction materials suppliers in Lagos, Nigeria. About 3-year old greenish-brown bamboo (Bambusa vulgaris) of 4.5 - $6.0 \mathrm{~m}$ average height of the same species sourced from different parts of Abeokuta, Nigeria were sliced into 10 - 12 mm bars. The average internodes distance was 250 - $400 \mathrm{~mm}$, external diameter of the trunk was 85 - $105 \mathrm{~mm}$, and the thickness was 10 - $15 \mathrm{~mm}$. The $10 \mathrm{~mm}$ size specimens were considered for the three investigated reinforcing materials. Likewise, mature West African rattans (Calamuc deerratus) were sourced from Ibadan, Nigeria and cut into several lengths of 10 - 12 mm diameter. Rattan stems cut and air dried for one month prior to cutting to standard lengths.

Fifty samples each of reinforcing bars of steel, bamboo and rattan bars whose diameters varied between 10 and $12 \mathrm{~mm}$ were subjected to tensile test procedure. All the specimens were cut to standard length $600 \mathrm{~mm}$ and gauge length $200 \mathrm{~mm}$. The ultimate tensile strength (UTS) is the maximum stress that a material can withstand while being stretched or pulled before failing or breaking, while the yield strength (YS) is the stress value beyond which deformations are completely irrecoverable upon removal of the load. The yield strength (YS), ul- 


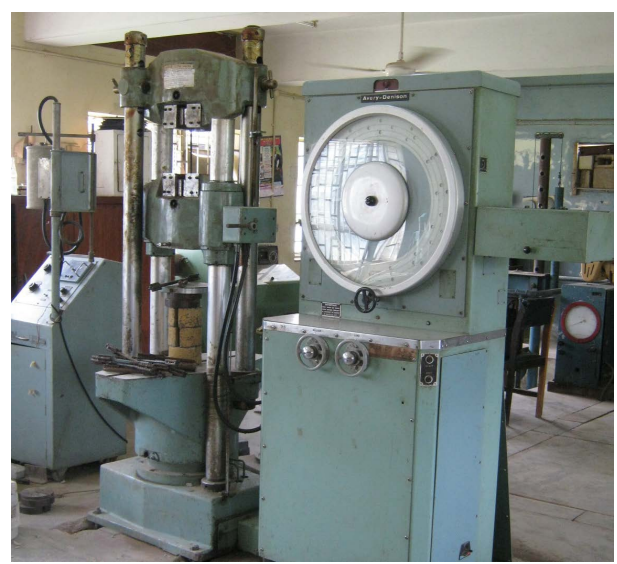

(a)

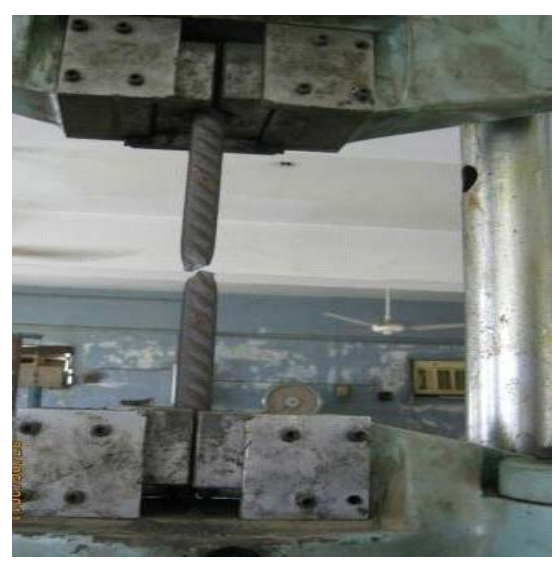

(b)

Figure 1. Tensile strength test setup (a) Avery UTM and (b) steel specimen at fracture.

timate tensile strength (UTS), elastic modulus (EM), and elongation (E) of the three rebar types were determined experimentally in accordance with ASTM A370 [49]. The yield stress of the bar samples was determined by offset method. Offset of $0.2 \%$ proof strain was applied to steel, while $0.5 \%$ offsets applied to timber and rattan bars. The statistical distribution trend was determined and the characteristic yield strength below which not more than 5 percent will fall was determined for the three materials.

\subsection{Flexural Strength Investigation of RC Beams}

Ordinary Portland cement of grade 32.5 was used. The aggregates which comprises river sand and crushed granite of $15 \mathrm{~mm}$ maximum nominal size conforming to BS 882 [50] were mixed at a water-cement ratio of 0.45 in accordance with BS 1881 [51]. The mix proportion of concrete of density is summarized in Table 1. The 7th and 28th compressive strength values of $150 \mathrm{~mm}$ concrete cube were 13.68 and $20.05 \mathrm{~N} / \mathrm{mm}^{2}$ respectively, and the 28th day density was $2404 \mathrm{~kg} / \mathrm{m}^{3}$.

Eighteen $150 \times 150 \times 900 \mathrm{~mm}$ concrete beam specimens were produced and grouped into three. The reinforcement ratio of 0.35 percent of the concrete area was adopted for all the beams corresponding to $4 \Phi 10 \mathrm{~mm}$ bars (two bars each at the tension and compression zones). The stirrups were $10 \Phi 8 \mathrm{~mm}$ steel bars spaced at 100 $\mathrm{mm}$ centres and the nominal cover was $20 \mathrm{~mm}$. The first group of six beams was reinforced with steel reinforcing bars, the second with bamboo and the last with rattan bars. The geometric and reinforcement details of the RC beams for flexural tests are illustrated in Figure 2, while the experimental setup is shown in Figure 3. A hydraulic actuator was used to apply a central concentrated load to the RC beam in $0.1 \mathrm{kN}$ increments. A linear variable differential transformers (LVDT) was used for each specimen to measure the vertical displacements at the mid-span under the applied load. A load cell was used to monitor applied load and a data acquisition system was used to record the experimental measures.

The study comparatively evaluated the flexural behaviour of concrete beams reinforced with steel, bamboo and rattan at ages 28 and 168 days. However, the experimental investigation revealed no remarkable difference in the flexural behaviour of the each of the three groups at ages 28 and 168 days. The stiffness and flexural capacities of concrete beams reinforced with steel, bamboo and rattan were experimentally determined at first cracking and ultimate failure loads.

\section{Experimental Results}

\subsection{Tensile Parameters and Statistical Distributions of Reinforcing Materials}

Yield stress (YS) and ultimate tensile stress (UTS) were extracted from the stress-strain curve with the proof strain taken as offset parallel to the linear part of the stress-strain relation. The elongation was measured in percentage of the original length. The YS of rattan, bamboo and steel were 58.46, 201.14 and $442.73 \mathrm{~N} / \mathrm{mm}^{2}$ respectively, while the UTS were $85.35,335.23$ and $540.13 \mathrm{~N} / \mathrm{mm}^{2}$ in the same order. It is obvious that the results summary in Table 2 that all the three reinforcing bar types met the requirements for the minimum stress ratio of 


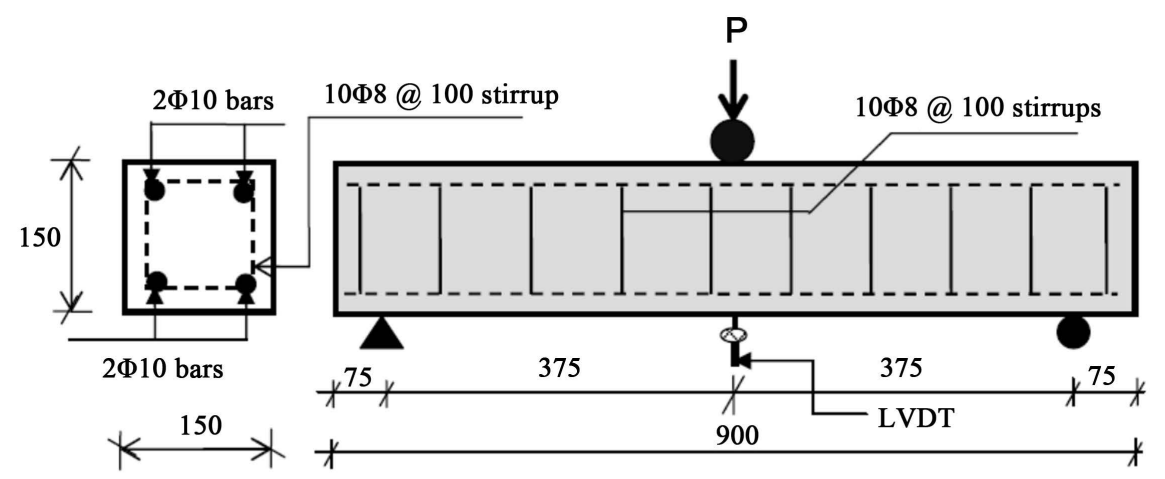

All dimensions in mm

Figure 2. Flexural test setup of RC beams indicating geometric and reinforcement details.

Table 1. Mix proportioning of constituents of concrete.

\begin{tabular}{ccccc}
\hline & Water & Cement & Fine aggregates & Coarse aggregates \\
\hline Mass (kg) & 110 & 245 & 761 & 1288 \\
Ratio & 0.45 & 1.00 & 3.10 & 5.26 \\
\hline
\end{tabular}

Table 2. General statistical tensile parameters of rattan, bamboo and steel bars.

\begin{tabular}{|c|c|c|c|c|c|c|}
\hline Material & Parameters & Yield strength (YS) & UTS $\left(\mathrm{N} / \mathrm{mm}^{2}\right)$ & Stress ratio, & $\frac{\text { UTS }}{\mathrm{YS}}$ & Elongation (\%) \\
\hline \multirow{6}{*}{ Rattan } & Mean, $\mu\left(\mathrm{N} / \mathrm{mm}^{2}\right)$ & 58.46 & 85.35 & 1.46 & & 10.00 \\
\hline & $\mathrm{SD}, \sigma\left(\mathrm{N} / \mathrm{mm}^{2}\right)$ & 5.71 & 7.28 & 0.15 & & 2.29 \\
\hline & COV (\%) & 9.76 & 8.53 & 10.09 & & 22.90 \\
\hline & $\mu+1.64 \sigma\left(\mathrm{N} / \mathrm{mm}^{2}\right)$ & 67.82 & & & & \\
\hline & $\mu-1.64 \sigma\left(\mathrm{N} / \mathrm{mm}^{2}\right)$ & 49.10 & & & & \\
\hline & Range & $46-75$ & & & & $8-14$ \\
\hline \multirow{6}{*}{ Bamboo } & Mean, $\mu\left(\mathrm{N} / \mathrm{mm}^{2}\right)$ & 201.14 & 335.23 & 1.67 & & 7.42 \\
\hline & $\mathrm{SD}, \sigma\left(\mathrm{N} / \mathrm{mm}^{2}\right)$ & 6.06 & 15.05 & 0.07 & & 2.11 \\
\hline & COV (\%) & 3.01 & 4.49 & 5.58 & & 28.44 \\
\hline & $\mu+1.64 \sigma\left(\mathrm{N} / \mathrm{mm}^{2}\right)$ & 211.09 & & & & \\
\hline & $\mu-1.64 \sigma\left(\mathrm{N} / \mathrm{mm}^{2}\right)$ & 191.20 & & & & \\
\hline & Range & $188-218$ & & & & $4-10$ \\
\hline \multirow{6}{*}{ Steel } & Mean, $\mu\left(\mathrm{N} / \mathrm{mm}^{2}\right)$ & 442.73 & 540.13 & 1.22 & & 14.7 \\
\hline & $\mathrm{SD}, \sigma\left(\mathrm{N} / \mathrm{mm}^{2}\right)$ & 33.23 & 51.91 & 0.11 & & 2.06 \\
\hline & COV (\%) & 7.50 & 9.61 & 9.16 & & 14.01 \\
\hline & $\mu+1.64 \sigma\left(\mathrm{N} / \mathrm{mm}^{2}\right)$ & 497.22 & & & & \\
\hline & $\mu-1.64 \sigma\left(\mathrm{N} / \mathrm{mm}^{2}\right)$ & 388.24 & & & & \\
\hline & Range & $354-541$ & & & & $12-23$ \\
\hline
\end{tabular}




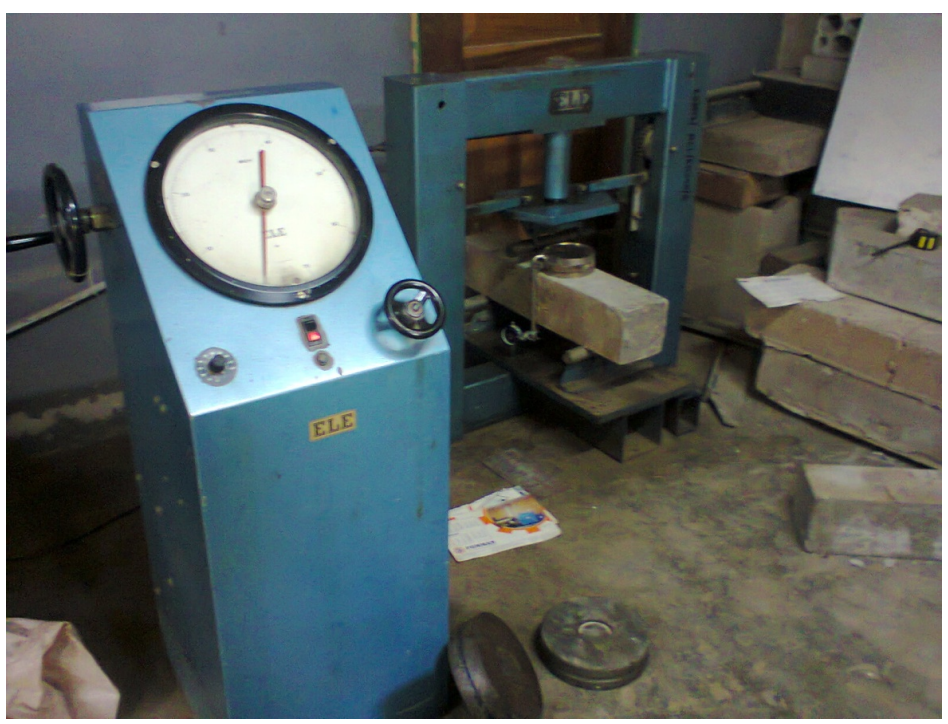

Figure 3. Experimental setup of concrete beams RB, BB and SB.

1.08 specified by BS 4449 [48] with bamboo having the highest value of 1.67, followed by rattan (1.46), and finally steel (1.22). Moreover, it is noteworthy that bamboo did not meet the minimum elongation requirement of $12 \%$ specification. However, steel fully satisfied the specifications for reinforcing bars, but rattan marginally fulfilled this requirement. The Normal (Gaussian) random variable is almost certainly the most important distribution in structural reliability. For every sample yield strength $x$, mean strength value $\bar{x}$ and standard deviation $\sigma$, the Normal distribution function $f(x)$ of the yield stress values of the fifty experimental results expressed in Equation (1) was plotted against the individual yield stress.

$$
f(x)=\frac{1}{\sigma \sqrt{2 \pi}} \exp \left[-\frac{1}{2}\left(\frac{x-\bar{x}}{\sigma}\right)^{2}\right]
$$

Furthermore, further analysis of the tensile strength properties revealed that the tensile properties of rattan, bamboo and steel are normally distributed, that is Gaussian distribution. The normal distribution curves of the yield stress for the three reinforcing materials are presented in Figure 4.

Limits state design is based on statistical concepts and on the application of statistical methods to the variations that occur in practice. The characteristic yield strength $f_{y k}$, of the reinforcing materials was determined as the value of the yield stress below which not more than $5 \%$ of the test material may be expected to fall (BS 4449 [48] and BS 8110 [52]). Thus, the characteristic strengths of the reinforcing bar types were estimated as the mean strength value, $\bar{x}$, less 1.64 times the standard deviation, $\sigma$.

Consequently, the characteristic yield strength of rattan, bamboo and steel bars were 49.10, 191.20 and 388.24 $\mathrm{N} / \mathrm{mm}^{2}$ respectively. These were in agreement with the findings of Mahzuz et al. [41], Mahzuz et al. [36], Mahzuz et al. [39], Akinyele and Olutoge [47] and Obilade and Olutoge [53]. The tensile parameters of bamboo disagree with the findings of Falade and Akeju [26] [27] and Alade et al. [34]. In addition, the degree of randomness measured by the coefficient of variation showed that none of the parameters was up to 30\% implying that the tensile properties are statistically reliable as indicated by the permissible deviations from the mean values.

\subsection{Flexural Behaviour of Concrete Beams Reinforced with Steel, Bamboo and Rattan Bars}

Nine $150 \times 150 \times 900$ mm RC beams symmetrically placed between simple supports spaced at $750 \mathrm{~mm}$ effective span. Three replicas of the beam specimens were reinforced with bamboo, rattan and steel longitudinal bars and denoted as bamboo RC beams (BB), rattan RC beams (RB) and steel RC beams (SB). The longitudinal bars of diameter $10 \mathrm{~mm}$ were sliced from rattan and bamboo, while reinforcing steel bars were also of $10 \mathrm{~mm}$ size. Mild steel of $8 \mathrm{~mm}$ diameter were employed as stirrups to resists shear for the three RC beam types. 

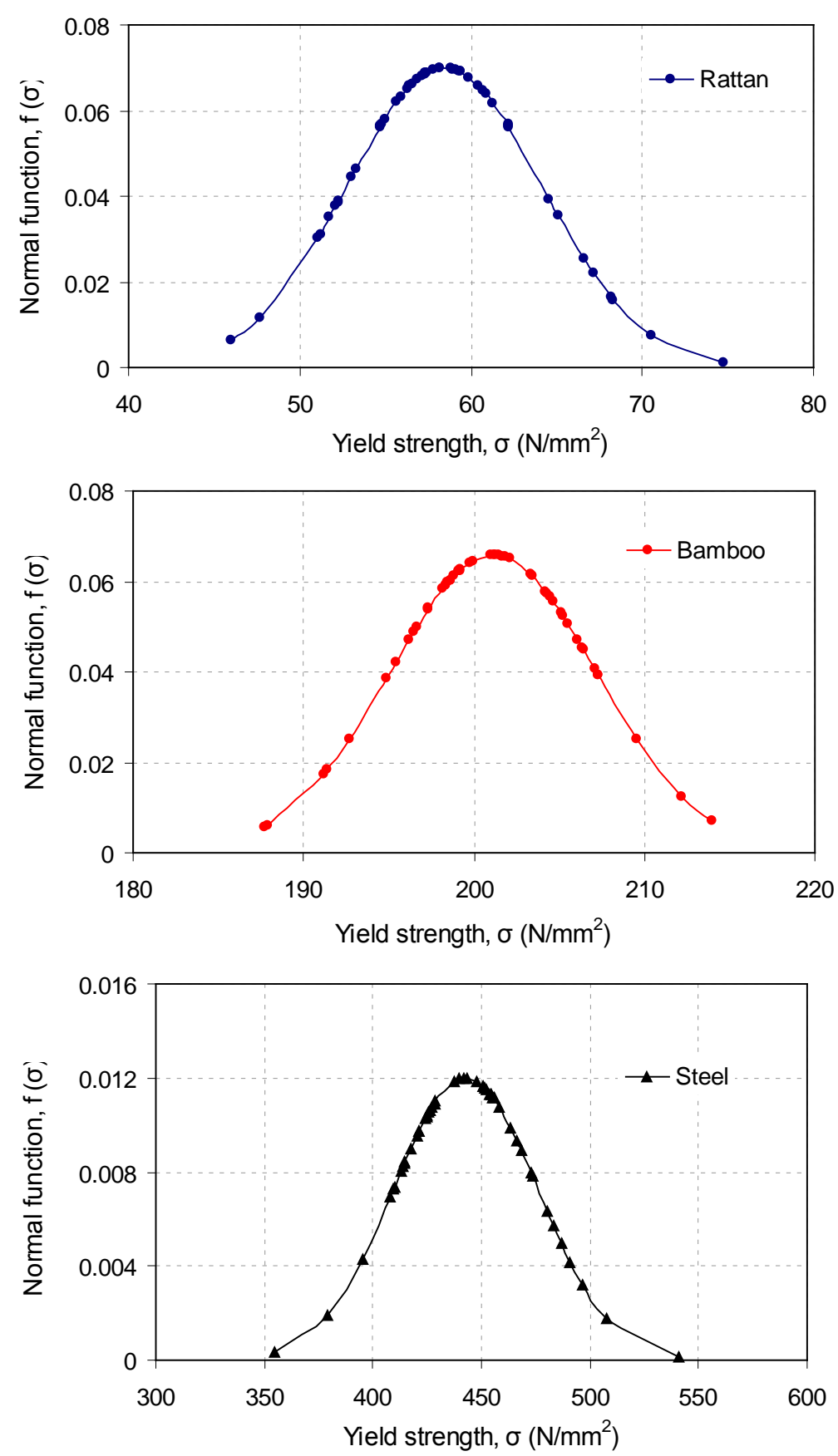

Figure 4. Normal distribution curve for yield strength of rattan, bamboo and steel bars.

For clear comparative evaluation of the flexural behavior of $\mathrm{BB}, \mathrm{RB}$ and $\mathrm{SB}$, the mean load-deflection $(\mathrm{P}-\delta)$ curves of beam samples reinforced with each of the reinforcing materials are shown in Figure 5. The curves steel RC beams had the highest stiffness, while rattan RC beams had the least. Although, the three curves are quadratic, the $\mathrm{P}-\delta$ plots of rattan RC beams can still be regarded as being linear until the beam ruptured. The load-deflection curve of the bamboo RC beams (BB) can be expressed as $P=-0.0794 \delta^{2}+2.6021 \delta-1.2808$ $\left(\mathrm{R}^{2}=0.968\right)$, rattan $\mathrm{RC}$ beams $(\mathrm{RB})$ is related by $P=0.0064 \delta^{2}+0.7364 \delta-0.1738 \quad\left(\mathrm{R}^{2}=0.984\right)$ and steel $\mathrm{RC}$ beams (SB) can be represented by $P=-0.4766 \delta^{2}+8.5301 \delta-0.6182\left(\mathrm{R}^{2}=0.997\right)$. The average stiffness val- 


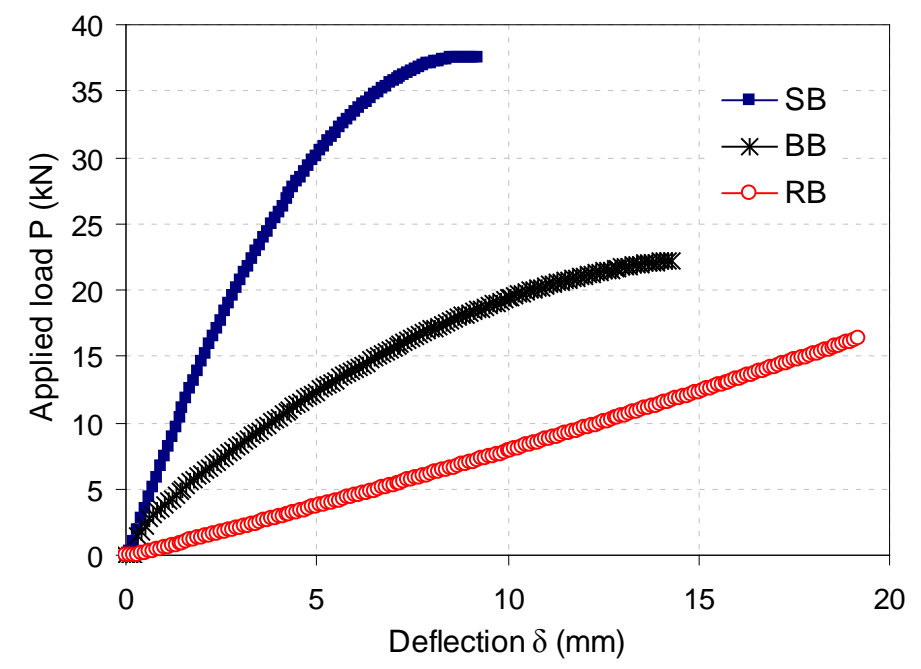

Figure 5. Load-deflection curved for bamboo, rattan and steel RC beams.

ues of BB, RB and SB were $1.97 \mathrm{~N} / \mathrm{mm}$ (or $1970 \mathrm{kN} / \mathrm{m}$ ), $0.83 \mathrm{~N} / \mathrm{mm}$ (or $830 \mathrm{kN} / \mathrm{m}$ ), and $6.147 \mathrm{~N} / \mathrm{mm}$ (or 6147 $\mathrm{kN} / \mathrm{m}$ ) respectively. Hence, it can be inferred that the flexural stiffness of bamboo and rattan RC beams were about $32 \%$ and $14 \%$ respectively of the conventional steel bars RC beams.

The flexural behavior in terms of the first crack load $F_{c}$, ultimate failure load, $F_{u}$ and the flexural strength (otherwise referred to as the modulus of rupture) for BB, RB and SB are summarized in Table 3 . The ratios of the first cracking loads to the experimental ultimate failure load, $\frac{F_{c}}{F_{u}}$ were 59,75 and 59\% for bamboo, rattan and steel bars RC beams respectively. This implies that the post-first crack residual load carrying capacities of bamboo and steel RC beams were 41 percent of the ultimate values, while rattan RC beams had only 25 percent. It can be inferred that rattan, except if pretreated for strengthening, had exhausted substantial percentage of the load-carrying at first crack. The first cracking loads of bamboo and rattan RC beams were $55 \%$ and 30\% respectively of the conventional steel RC beams.

It can be deduced from these findings that SB had the highest resilience after the first crack, while rattan had the least. Relatively, this implies that steel RC beams still possessed $40 \%$ residual load-carrying capacity after the first crack. Bamboo RC beams exhibited similar pattern as it also had about $40 \%$ of the load-carrying capacity after the first crack, while rattan RC beam had only $25 \%$ left after the occurrence of the first crack. It can be inferred that RB had almost exhausted its capacity after the first crack. This is evident in the almost linear loaddeflection curve with barely any provision for second stiffness. In addition, the experimental ultimate failure loads of bamboo and rattan RC beams were $55 \%$ and $24 \%$ respectively of the conventional steel RC beams. This indicates that the carrying capacity of bamboo RC beams is about one-half of the conventional steel RC beams, while rattan RC beams were barely one-quarter of the steel RC beams capacities. The flexural strengths of bamboo, rattan and steel RC beams were $6.22,2.56$ and $12.22 \mathrm{~N} / \mathrm{mm}^{2}$. The indication of this is that the flexural strengths of bamboo and rattan RC beams were $51 \%$ and $21 \%$ respectively of the conventional steel RC beams.

Table 4 summarizes the failure mode as well as the pattern and width of cracks in the RC beams. The mode of failure for bamboo and steel RC beams was shear, indicated by diagonal cracks, because of the relatively higher tensile strength of steel rebars than the rattan RC beams which failed by flexure (vertical cracks). For BB and SB, the reinforcement was adequate to resist the moment at the midspan. However, shear was at its maximum at the support which coincided with the location of the maximum crack widths. On the other hand for rat$\tan$ RC beam with low yield strength, the flexural mode of failure preceded the shear mode of failure as indicated by the vertical cracks neat the middle of the span.

In addition, the experimental maximum crack width for bamboo, rattan and steel RC beams were 9.3, 6.7 and $7.0 \mathrm{~mm}$. The rattan RC beams had the minimum crack widths because of the flexural mode of failure under relatively smaller ultimate failure load. On the contrary, bamboo and steel RC beams failed under a comparatively higher load due to shear. The knife-edge condition informed the pattern and size of crack propagation. 
Table 3. First crack and failure loads for beams.

\begin{tabular}{ccccc}
\hline Beam No. & First crack load, $\mathrm{F}_{\mathrm{c}}(\mathrm{kN})$ & Ultimate failure load, $\mathrm{F}_{\mathrm{u}}(\mathrm{kN})$ & $\frac{\mathrm{F}_{\mathrm{c}}}{\mathrm{F}_{\mathrm{u}}}$ & Flexural strength $\left(\mathrm{N} / \mathrm{mm}^{2}\right)$ \\
\hline Bamboo RC-BB & 11 & 18.67 & 0.59 & 6.22 \\
Rattan RC-RB & 6 & 8 & 0.75 & 2.56 \\
Steel RC-SB & 20 & 34 & 0.59 & 12.22 \\
\hline
\end{tabular}

Table 4. Failure mode and crack characteristics.

\begin{tabular}{cccc}
\hline Beam No. & Mode of failure & Type of crack at failure & Experimental maximum crack width (mm) \\
\hline Bamboo RC-BB & Shear & Diagonal & 9.3 \\
Rattan RC-RB & Flexural & Vertical & 6.7 \\
Steel RC-SB & Shear & Diagonal & 7.0 \\
\hline
\end{tabular}

\section{Conclusions}

The following salient conclusions can be drawn from the study.

1) The tensile properties of the three reinforcing materials are normally distributed and their stress ratios satisfied the minimum requirement value of 1.08 . The strength of rattan and bamboo represented 13 and $45 \%$ of that of steel reinforcing bars.

2) The elongation of bamboo did not meet the ductility requirements of $12 \%$, rattan marginally satisfied this, but steel rebars fully met the requirements.

3) Bamboo and rattan can only be used for lightweight RC structures. The flexural stiffness of bamboo and rattan RC beams was about $32 \%$ and $13.5 \%$ respectively of the conventional steel bars RC beams. The first cracking loads of bamboo and rattan RC beams were $55 \%$ and $30 \%$ respectively of the conventional steel RC beams. The experimental ultimate failure loads of bamboo and rattan RC beams were 51\% and $21 \%$ respectively of the conventional steel RC beams.

4) Bamboo and steel RC beams had $40 \%$ residual capacity after the first crack, while rattan RC beams had exhausted $75 \%$ of its load-carrying capacity after the first crack.

5) The mode of failure for bamboo and steel RC beams was shear, indicated by diagonal cracks because of the short-span specimen adopted and the relatively higher tensile strength than the rattan RC beams which failed by flexure (vertical cracks).

6) The flexural and bonding strengths of bamboo and rattan RC beams could be enhanced by bonding galvanized iron or fibre thread spirally round the surface of the bars with epoxy.

\section{References}

[1] Adewuyi, A.P., Wu, Z.S. and Serker, N.H.M.K. (2009) Assessment of Vibration Based Damage Identification Methods Using Displacement and Distributed Strain Measurements. International Journal of Structural Health Monitoring, 8, 443-461. http://dx.doi.org/10.1177/1475921709340964

[2] Adewuyi, A.P., Wu, Z.S. and Raheem, A.A. (2010) Adaptation of Vibration-Based SHM for Condition Assessment and Damage Detection of Civil Infrastructure Systems. LAUTECH Journal of Engineering \& Technology, 6, 1-11.

[3] Adewuyi, A.P. and Wu, Z.S. (2011) Vibration-Based Damage Localization in Flexural Structures Using Normalized Modal Macrostrain Techniques from Limited Measurements. Computer-Aided Civil and Infrastructure Engineering, 26, 154-172. http://dx.doi.org/10.1111/j.1467-8667.2010.00682.x

[4] Neville, A.M. (2004) Properties of Concrete. 4th Edition, Addision Wesley Longman, Edinburgh.

[5] Kosmatka, S.H., Kerkhoff, B. and Panarese, W.C. (2003) Design and Control of Concrete Mixtures. 14th Edition. Portland Cement Association, Skokie.

[6] Mehta, P.K. and Monteiro, P.J.M. (2006) Concrete: Microstructure, Properties, and Materials. 3rd Edition. McGrawHill, New York.

[7] Mosley, W.H., Bungey, J.H. and Hulse, R. (1999) Reinforced Concrete Design. 5th Edition, Macmillan Education Li- 
mited, Houndmills, Basingstoke.

[8] Adewuyi, A.P. and Ola, B.F. (2005) Application of Waterworks Sludge as Partial Replacement for Cement in Concrete Production. Science Focus Journal, 10, 123-130.

[9] Adewuyi, A.P. and Adegoke, T. (2008) Exploratory Study of Periwinkle Shells as Coarse Aggregates in Concrete Works. Journal of Engineering and Applied Sciences, 3, 1-5.

[10] Basu, P.C., Shylamoni P. and Roshan A.D. (2004) Characterization of Steel Reinforcement for RC Structures: An Overview and Related Issues. Indian Concrete Journal, 78, 19-30.

[11] Olaniyi, O.A. (2013) Performance Assessment of Typical Steel Rebars for Practical Reinforced Concrete Structures. An Unpublished Master of Technology Dissertation, Ladoke Akintola University of Technology, Ogbomoso.

[12] Kolade, O.O. (2015) Characterization of Steel Reinforcing Bars in the Nigerian Market and Performance Evaluation in Concrete Structures. An Unpublished Master of Engineering Dissertation, Federal University of Agriculture, Abeokuta.

[13] Nawy, E.G., Neuwerth, G.E. and Phillips, C.J. (1971) Behavior of Fiber Glass Reinforced Concrete Beams. Journal of the Structural Division, 97, 2203-2215.

[14] Nawy, E.G. and Neuwerth, G.E. (1977) Fiberglass Reinforced Concrete Slabs and Beams. Journal of the Structural Division, 103, 421-440.

[15] Yamasaki, Y., Masuda, Y., Tanano, H. and Shimizu, A. (1993) Fundamental Properties of Continuous Fiber Bars. In: Nanni, A. and Dolan, C.W., Eds., Proceedings of the Symposium on Fiber Reinforced Polymer Reinforcement for Concrete Structures, American Concrete Institute, Detroit, 715-730.

[16] Faza, S.S. and GangaRao, H.V.S. (1991) Bending Response of Beams Reinforced with FRP Rebars for Varying Concrete Strengths. In: Iyer, S. and Sen, R., Eds. Proceedings of the ASCE Specialty Conference on Advanced Composites in Civil Engineering Structures, American Society of Civil Engineers, New York, 262-270.

[17] Bakis, C.E., Bank, L.C., Brown, V.L., Cosenza, E., Davalos, J.F., Lesko, J.J., Machida, A., Rizkalla, S.H. and Triantafillou, T.C. (2002) Fiber-Reinforced Polymer Composites for Construction-State-of-the-Art Review. Journal of Composites for Construction, 6, 73-87. http://dx.doi.org/10.1061/(ASCE)1090-0268(2002)6:2(73)

[18] Andonian, P., Mai, Y.M. and Cotterell, B. (1979) Strength and Fracture Properties of Cellulose Fibre Reinforced Cement Composites. International Journal of Cement Composite Lightweight Concrete, 1, 151-158.

[19] Manzur, M.A. and Aziz, M.A. (1982) A Study of Jute Fibre Reinforced Cement Composites. International Journal of Cement Composite Lightweight Concrete, 4, 75-82. http://dx.doi.org/10.1016/0262-5075(82)90011-2

[20] Kankam, J.A., Ben-George, M. and Perry, S.H. (1988) Bamboo-Reinforced Beams Subjected to Third-Point Loading. ACI Structural Journal, 85, 61-67.

[21] Kankam, C.K. (1997) Raffia Palm-Reinforced Concrete Beams. Materials and Structures, 30, 313-316. http://dx.doi.org/10.1007/bf02486356

[22] Kankam, C.K. (1994) The Influence Of Palm Stalk Fibre Reinforcement on the Shrinkage Stresses in Concrete. Journal of Ferrocement, 24, 3-12.

[23] Schreckenbach, H. and Abenkwa, J.G.K. (1982) Construction Technology for a Tropical Developing Country. German Agency for Technical Cooperation (GTZ) for the Department of Architecture, University of Science and Technology, Kumasi.

[24] McClure, F.A. (1966) The Bamboos. Harvard University Press, Cambridge. http://dx.doi.org/10.4159/harvard.9780674428713

[25] Austin, R. and Ueda, K. (1972) Bamboo. Weather Hill Publishing, New York.

[26] Falade, F.A. and Akeju, T.A.I. (2002) The Behaviour and Analysis of Bamboo Reinforced Concrete under Flexural Loading. Proceedings of the Fifth International Conference on Structural Engineering Analysis and Modeling, Accra, 26-28 March 2002, 277-288.

[27] Falade, F.A. and Akeju, T.A.I. (2002) Structural Design and Economy of Bamboo Reinforced Concrete Beams. Proceedings of the Fifth International Conference on Structural Engineering Analysis and Modeling, Accra, 26-28 February 2002, 215-228.

[28] Chembi, A. and Nimityongskul, P. (1989) A Bamboo Reinforced Cement Water Tank. Journal of Ferrocement, 19, 117.

[29] Winarto, Y.T. (1989) Rainwater Collection Tanks Constructed on Self Help Basis. Journal of Ferrocement, 19, 247254.

[30] Ghavami, K. (1995) Ultimate Load Behaviour of Bamboo-Reinforced Lightweight Concrete Beams. Cement and Concrete Composite, 17, 281-288. http://dx.doi.org/10.1016/0958-9465(95)00018-8

[31] Venkateshwarlu, D. and Raj, V. (1989) Development of Bamboo Based Ferrocement Roofing Elements for Low Cost 
Housing. Journal of Ferrocement, 19, 331-337.

[32] Raj, V. (1990) Large Span Bamboo Ferrocement Elements for Flooring and Roofing Purposes. Journal of Ferrocement, 20, 367-375.

[33] Kankam, J.A., Ben-George, M. and Perry, S.H. (1986) Bamboo-Reinforced Concrete Two-Way Slabs Subjected to Concentrated Loading. Structural Engineering, 64, 85-92.

[34] Alade, G.A., Olutoge, F.A. and Alade, A.A. (2004) The Durability and Mechanical Strength Properties of Bamboo in Reinforced Concrete. Journal of Applied Science, Engineering and Technology, 1, 35-40.

[35] Akeju, T.A.I. and Falade, F.A. (2001) Utilization of Bamboo as Reinforcement in Concrete for Low-Cost Housing. Proceedings of the International Conference on Structural Engineering, Mechanics and Computation, Cape Town, 2-4 April 2001, 1463-1470. http://dx.doi.org/10.1016/B978-008043948-8/50164-8

[36] Mahzuz, H.M.A., Ahmed, M., Uddin, M.K., Hossain, M.M. and Saquib, N. (2013) Determination of Tensile Stress and Bond Stress with Concrete of a Rattan (Calamus guruba). Scholars Journal of Engineering and Technology, 1, 39-43.

[37] Ghavami, K. (2005) Bamboo as Reinforcement in Structural Concrete Elements. Cement \& Concrete Composites, 27, 637-649. http://dx.doi.org/10.1016/j.cemconcomp.2004.06.002

[38] Baba, M. (2009) Mini Project Report on Shed Type Structures-Steel vs. Bamboo. Department of Civil Engineering, Indian Institute of Technology, Delhi.

[39] Mahzuz, H.M.A., Ahmed, M., Ashrafuzzaman, M., Karim, R. and Ahmed, R. (2011) Performance Evaluation of Bamboo with Mortar and Concrete. Journal of Engineering and Technology Research, 3, 342-350.

[40] Chowdhury, M.Q. (2004) Assessment of Some Physical and Mechanical Properties of Golla Bet (Daemonorops jenkinsiana) from North-Eastern Region of Bangladesh. Bamboo and Rattan, 3, 195-201. http://dx.doi.org/10.1163/1569159041765353

[41] Mahzuz, H.M.A., Ahmed, M., Uddin, M.K., Hossain, M.M. and Saquib, N. (2014) Effectiveness Evaluation of Zali Bet as Reinforcement in Concrete Beam. Civil Engineering and Architecture, 2, 269-279.

[42] Lucas, E.B. and Dahunsi, B.I.O. (2004) Bond Strength in Concrete of Canes from Three Rattans Species. Journal of Applied Science, Engineering and Technology, 4, 1-5.

[43] Cox, F.B. and Geymayer, H.G. (1969) Expedient Reinforcement for Concrete for Use in South East Asia: Report 1Preliminary Test for Bamboo Technical Report No. C-69-3, US Army Corps of Engineers.

[44] Youssef, M.A.R. (1976) Bamboo as a Substitute for Steel Reinforcement in Structural Concrete. In: Fang, H.Y., Ed., New Horizons in Construction Materials, Envo Publishing Co., Leligh Valley, 525-554.

[45] Neville, A.M. and Brook, J.J. (1987) Concrete Technology. Longman Group, London.

[46] Lucas, E.B. and Dahunsi, B.I.O. (2004) Characteristics of Three Western Nigerian Rattan Species in Relation to Their Utilization as Construction Material. Journal of Bamboo and Rattan, 3, 45-56. http://dx.doi.org/10.1163/156915904772875635

[47] Akinyele, J.O. and Olutoge, F.A. (2011) Properties of Rattan Cane Reinforced Concrete Façade Subjected to Axial Loading. Journal of Civil Engineering and Architecture, 5, 1048-1052.

[48] BS 4449 (2001) Hot Rolled Steel Bars for Reinforcement of Concrete, Part 2. British Standards Institution, London.

[49] ASTM (2003) Standard Test Methods and Definitions for Mechanical Testing of Steel Products—ASTM A 370. West Conshohocken.

[50] BS 882 (1992) Specification for Aggregates from Natural Sources for Concrete. British Standards Institution, London.

[51] BS 1881 (2013) Testing Concrete. Methods for Mixing and Sampling Fresh Concrete in the Laboratory, Part 125. British Standards Institution, London.

[52] BS 8110 (2004) Code of Practice for Structural Use of Concrete, Part 1. British Standards Institution, London.

[53] Obilade, I.O. and Olutoge, F.A. (2014) Flexural Characteristics of Rattan Cane Reinforced Concrete Beams. International Journal of Engineering and Science, 3, 38-42. 